\title{
METHODOLOGY OF ECONOMIC THROUG EFFECT ON THE REENGINEERING PROCESS OG ORGANIZING IN SMALL OR MEDIUM-SIZED ENTERPRISES
}

\author{
Prof. Ph. D. eng. Slobodan Stefanovic \\ Graduate mechanical engineer and professor (doctor of Technical Sciences, doctor of Economic Sciences), \\ Advanced (High) school of applied professional studies, Vranje, Serbia
}

SUMMARY: The design of small and medium enterprises by re-engineering must be comprehensive (systemic approach) and that there is an effective methodology that depends on specific companies. The specific needs of companies dictate the levels of its complexity, the degree of detail and implementation timetable reengineering in its implementation.

Key words: economic effects, monitoring and process control, reengineering methodology, medium enterprises, economic parameters.

\section{INTRODUCTION}

The design of small and medium enterprises by re-engineering must be comprehensive (systemic approach) and that there is an effective methodology that depends on specific companies. The specific needs of companies dictate the levels of its complexity, the degree of detail and implementation timetable reengineering in its implementation.

Reengineering methodology in SMEs will be displayed in six main stages:

1. Create a vision, planning and initiation of re-engineering of these types of companies,

2. Research and define the success of these enterprises,

3. Production innovation process in these companies,

4. Transformation of these companies under the new concept of using the basics of reengineering,

5. Implementation of these processes reengineering companies,
6. Monitoring and process control applications reengineering of these companies.

For the implementation of each stage in the methodology of application re-engineering is necessary preparation and application of reliable methodologies. Management of these companies has far-reaching reflect, openly and boldly, to challenge the traditional doctrine of the organization of enterprises and to create new applications in the spirit of reengineering. Only in this way will increase the productivity of a company directly stim will increase the income tax.

Reengineering methodology in SMEs should include a systematic approach that is based on that each organizational unit must be considered individually and that each of them to form a functional teams (Reengineering Team) which must be composed of people with appropriate levels of knowledge and the appropriate skills in the work.

\section{Creating the vision, planning and initiating re-engineering in small and medium enterprises}

It includes the following four objectives as follows:

* form a vision of the company (to create and communicate a vision),

* establish and run a re-engineering methodology, 
* develop appropriate goals, measure performance and success of application reengineering,

* establish and communicate expectations by applying the results of reengineering.

The main processes of this phase of reengineering are the following:

* Creating a vision and goals of the change in the company that brings the application re-engineering processes,

* Recognition capabilities of the production process of enterprises,

* Building teams for implementation of reengineering (Reengineering Team),

* Communication of the vision of the company and gain confidence in the market,

* Creation infrastructure that process. providing support for top managers, who represent the highest part of the project management application reengineering,

* Planning the project through to its dimensioning and through his financial needs.

\section{Research and define the success of small and medium enterprises}

Through this process should be formulated where small or medium company needs to be developed and where such way to arrive. Activities to identify these processes include:

a) analyze the ability of small and medium enterprises and the competition circuit,

b) identification of the external environment, ie. environment in which business is small or medium enterprise,

c) assessment of needs, abilities and limitations in which business is small or medium enterprise,

d) estimates that use of others' experiences. Knowledge of competitive enterprises in the production of the same product, e) assessing the level of risk the introduction of re-engineering processes in the organization of small and medium enterprises,

f) determining the precise and convincing presentation of the vision of top management of this enterprise.

3 and 4. Innovations in manufacturing processes of these enterprises by introducing projects that include re-engineering and transformation of these companies under the new concept of using the basics of reengineering

This process involves the following stages of introducing and re-engineering to:

a) evaluation of business and organizational risk of certain production processes by introducing the re-engineering,

b) the creation of the concept of the whole project with its methods and procedures using reengineering,

c) determining priorities and the crucial link between the different manufacturing processes of a small or medium-sized enterprises,

d) ensuring the effectiveness and cohesion of the team for reengineering.

5. and 6. The implementation of these processes re-engineering and enterprise monitoring and process control applications reengineering

Basic operations reengineering in these phases are reflected in recognizing the opportunities of small and medium enterprise market, the formation and training of teams for the reengineering and creating infrastructure for reengineering.

Identifying opportunities ie. opportunities for market success - This includes the need to identify all the tasks that make up the core processes of a small or medium size company and ubličiti them so that they become feasible to implement reengineering. In this process should be implemented: 
1. Prioritize the introduction of reengineering (this refers to the beginning start re-engineering of the company and prior to forming a team for the reengineering, because it significantly and directly affect the planning staff),

2. Process re-engineering also does not need to apply too much process,

3. Make use of selection criteria that include: the levels of business risks, advantages over the competition, resources, assessment of failure, time trejanje application process reengineering, etc..),

4. Necessary continuous and developing knowledge and continuous learning for all participants in the process reengineering applications (these are the skills, competencies and odgovrnosti team for reengineering).

The formation and training teams for reengineering - Reengineering teams are formed depending on the size of the company, the Cemi team members must be carefully selected and tested business. They are expected to have all of its energy business focus on the success of reengineering projects and be able to be continually refined and beginning to undergo intensive training in the field of innovation implementation process reengineering in the company.

Communicating the company vision and dedication to work - This section applies to all those who are directly or indirectly involved in project implementation in the production process re-engineering companies. These učesnisi must keep their expectations, that nešire rumors or give inaccurate information as to eliminate his concern that may arise on the introduction of reengineering the company.

Creation of infrastructure - This refers to the development and implementation:

1. Standards and procedures for project management related to reengineering,

2. Reporting on the status of the project related to reengineering,

3. Integration methods that are related to quality assurance procedures in the application reengineering.

\section{HOLDERS OF ECONOMIC EFFECTS REENGINEERING PROCESS}

The subject of the research carrier of the economic effects of reengineering should relate primarily to the manner of conducting the reengineering in small and medium enterprises, and include the following costs and savings to:

1. Economic parameters generated by completing and documenting a detailed re-engineering project that includes: a new organizational model in the company as well as the characters in the role of new jobs in the new organization; / parameter, $N E E_{N O}=N E E_{N P}, N E E_{N O}$ - the holder of the economic effect of the parameter related to the new organizational model, and it depends solely on the $N E E_{N P}$ - the holder of the economic effect of the parameter related to the character of the new jobs in the new organization of small and medium enterprises application reengineering.

2. Economic parameters that arise in the implementation of the system support the new organization of small and medium enterprises; / parameter $N E E_{S P}$ - parameter holder of the economic effects related to the implementation system support.

3. Economic parameters that arise implementing "pilot solutions" to the system support the new organization of small and medium enterprise companies using reengineering testing on a small scale of production; / parameter $N E E_{P R}$ - parameter holder economic effects related to the implementation of "pilot solutions."

4. Economic parameters which are general and apply to its employees on the planned changes and implementation of reengineering plan for the implementation of each phase; / parameter $N E E_{P P}$ - parameter holder economic effects related to the invested time needed to implement the planned changes and implementation of reengineering plan for the 
implementation in stages in the company.

5. Economic parameters which are general and apply to the training of personnel for the new process and new systems of work with the planned changes and implementation of reengineering plan for the implementation of each phase; / parameter $\mathrm{NEE}_{\mathrm{NSR}}{ }^{-}$parameter holder economic effects related to the costs incurred in training employees on new system of work.

In this way the total cost $\sum_{i=1}^{5} U K N_{\text {totalcosts }}$ incurred and are defined as carriers of economic parameters in the implementation of reengineering can be expressed by summing up all the listed parameters:

$$
\begin{aligned}
& \sum_{i=1}^{5} U K N_{\text {total costs }}=\left(N E E_{N O}=N E E_{N P}\right)+N E E_{N P}+N E E_{S P} \\
& +N E E_{P R}+N E E_{P P}+N E E_{N S R} . \\
& {[1]}
\end{aligned}
$$

\section{COST ANALYSIS OF THE PARAMETERS}

In addition to the basic cost of application re-engineering in small and medium enterprises, it is necessary to analyze the parameters and costs resulting from the implementation of business process reengineering activities and personnel that revitalization. adaptation of organizational structures in terms of ownership restructuring that includes four auxiliary hypotheses as follows:

1. The economic parameters of the financial recovery of a small or medium enterprises $N E E_{F S}$, the introduction of reengineering, which includes the introduction of integrated logical system in a small or medium size company.
2. Economic parameters that ensure the functioning of the enterprise to implement reengineering $N E E_{K P}$.

3. Economic parameters that ensure the functioning of all processes, structure and quality systems in small and medium enterprises uvođenjm reinženjringa $N E E_{S K}$.

4. Economic parameters that provide the competitive prices of products on the market resulting $N E E_{C P}$ in a production environment using the reengineering.

1. The economic parameters of the financial recovery of a small or medium enterprises $N E E_{F S}$, the introduction of reengineering, which includes the introduction of integrated logical system in a small or medium size company

The process of procurement, manufacturing and physical distribution are essential elements of integrated logical system a small or medium enterprises. Logically integrated system includes a logical domain in which the manifest activity and impact of integrated system that is logical. omeđava on the totality of logical functions.

The logical system of small and medium enterprise re-engineering techniques can be applied to the whole logic of the system or some of its selected processes.

Reengineering the logical systems of small or medium-sized enterprises is based on a system analysis that encourages interaction between the logical structure of systems and internal and external integration processes.

The initial framework for implementing the procedures are logical systems reengineering:

PHASE I: Determine the initial values of the logical performance $N E E_{\text {FSIPHASE }}$,

PHASE II: Measuring the performance of logical systems $N E E_{\text {FSIIPHASE }}$. 
The first stage involves determining the initial value of logistics performance. It analyzes the results compared to the values within a small or medium-sized enterprises (internal analysis) and by comparing them with the reengineering results successful competitive companies. The first form involves the use of logical data obtained on the basis of activities and publications of researchers and consultants (these are costs that occur during their engagement). Another form involves companies belonging to the associations and organizations (costs incurred paying membership in these organizations) that mediate between the cooperative members in the exchange of data used for the purpose of reengineering. The third form of the initiative includes companies that do the necessary data comes in contact with companies with which they are not in a direct competitive relationship (the cost of arrivals, departures and receiving delegation of companies).

The second phase includes the performance of the logistics enterprise system that includes a rough picture of the quality of the logistics system in the company as follows:

1. Inventory management strategy,

2. Responsiveness to customer needs

3. Number of adverse events.

The level of inventories indicates the efficiency of the logistics system and its ability to respond to the needs of the costs that should weigh a minimum (the cost of causing unnecessary stocks of spare parts, materials, semi-finished products).

Response times indicates an intention and ability of small and medium enterprises to meet market demand (a decrease in profit due to the untimely proizvdnje ie. Placing sufficient quantities of products on the market).

The number of adverse events in a logical system (failures of technical systems, poor quality products, damage to the goods products during handling and transport activities that are unnecessarily repeated) cause additional costs and also based on them are made from quality management policy, ie. evaluating the overall position on the quality of logical support.

Directly monitoring the effectiveness of logical systems before, during and after implementation of design solutions reengineering is done by introducing a system for continuous measurement and monitoring of logistics performance. On the basis of it can be followed:

1. Delivery time on order (which is less time and less cost),

2. Delivery time on products (which is less time and less cost),

3. Time of delivery per customer (which is less time and less cost),

4. During the registration order (which was a faster time to prepare for delivery, so the lower the costs),

5. Mean time between failures in the operation of technical systems (which is a long time productivity is higher and costs are reduced),

6. All other costs of the company (of them will be discussed later in this chapter).

\section{Economic parameters that ensure the functioning of the enterprise for the implementation of reengineering $N E E_{K P}$}

To provide entrepreneurship naophodno is that there are responsible carriers or entities that move, carried out in implementing the results of reengineering. By M. Hammer and J. Champy among the main protagonists of the process reengineering: Supervisory Board (Steerring Comittee), Reengineering Team Leader and processes. For W. Bennis and M. Mischela key nisioci reengineering are iszvršni sponsors, board of directors, transformational leader, protector, 
and process reengineering team. DK Carr and H. J. Johansson among the main participants in the process of reengineering include: Board of Directors (Executive Council), labor and process reengineering teams, line management and support staff - counselors.

Although there are some disparities in the division, they may find appropriate matches. These similarities arise core group of holders and process reengineering to:

1. Business Board of Executive Directors or higher (Steerring Comittee) or Board of Directors,

2. Reengineering team (working or process reengineering teams),

3. leader process (transformational leaders).

Economic parameters that ensure the functioning of the enterprise to implement reengineering influence on the income of small and medium enterprises in terms of providing basic salary carrier group process reengineering.

\section{Ekonomske parametre koji} obezbeđuju procese funkcionisanja svih struktura i sistema kvaliteta u malim i srednjim preduzećima uvođenjem reinženjeringa $N E E_{S K}$

Each team manager for the implementation of reengineering in SMEs must actively participate in managing the process reengineering: a quality system in praduzeću, production system, system maintenance, system organization and management companies and others. In order to have success postugne it is necessary to constantly monitor and improve the quality system in a company that includes a number of subsystems that have their own economic parameters and actively participate in the formation of prices of products such as:
2. a network of accredited laboratories $N E E_{I M}$,

3. Economic parameters resulting from the formation of internal standardization $N E E_{\text {IS }}$,

4. Economic parameters resulting from the formation of the system reliability of technical systems and energy facilities and infrastructure (technology implementation and maintenance) $N E E_{T O}$,

5. Economic parameters resulting from the formation of the system design $N E E_{D}$,

6. Economic parameters resulting system of deposit formation, destruction and recycling of products obtained poor $N E E_{\text {DUR }}$,

7. Economic parameters resulting from the establishment of quality systems support posprodajne $N E_{P P P}$,

8. Economic parameters resulting from the establishment of quality systems support posprodajne $N E E_{D I}$.

The above overall economic setting that provides the processes of functioning of all structures and quality systems in small and medium enterprises by introducing reengineering can be expressed:

$$
\begin{aligned}
& N E E_{S K}=N E E_{I M}+N E E_{I S}+N E E_{T O}+N E E_{D}+ \\
& N E E_{D U R}+N E E_{P P P}+N E E_{D I} .
\end{aligned}
$$

4. Economic parameters that provide the competitive prices of products on the market $N E E_{C P}$ generated in the production environment using the reengineering

They include objectives and measures of financial prospects of companies. In Table 1. will be made to display them.

1. Economic parameters resulting from the formation of the internal metrology with 
Table 1. The objectives and measures of financial companies perspective

\begin{tabular}{|c|c|c|}
\hline PERSPECTIVE & OBJECTIVES & STANDARDS \\
\hline \multirow{4}{*}{$\begin{array}{l}\text { Consumers in } \\
\text { company }\end{array}$} & New Products & Percentage of sales of new products $N E E_{C_{1}}$ \\
\hline & Peripheral suppliers & Participation in procurement of key customer \\
\hline & Responsible supply customers & Timely delivery of products $N E E_{\mathrm{CP}_{2}}$ \\
\hline & Partnership with customers & Number of joint projects with customers \\
\hline \multirow{4}{*}{$\begin{array}{l}\text { Internal processes in the } \\
\text { enterprise }\end{array}$} & Production perfection & Cycle time - The unit costs $N E E_{\mathrm{CP}_{3}}$ \\
\hline & Design productivity & - \\
\hline & $\begin{array}{l}\text { The introduction of new } \\
\text { products }\end{array}$ & $\begin{array}{l}\text { Actual and planned course of introducing new products } \\
N E E_{\mathrm{CP}_{4}}\end{array}$ \\
\hline & Technological leadership & During the development of a new generation $\mathrm{NEE}_{\mathrm{CP}_{5}}$ \\
\hline \multirow{3}{*}{$\begin{array}{l}\text { Innovation and learning } \\
\text { in the enterprise }\end{array}$} & Production learning & Time of the capture of the production process $N E E_{C P 6}$ \\
\hline & \multicolumn{2}{|r|}{ The percentage of products that provides $80 \%$ of sales } \\
\hline & $\begin{array}{l}\text { Time is now introducing a new } \\
\text { product }\end{array}$ & According to the time of competition \\
\hline \multirow{3}{*}{ Finance Company } & Survival & Cash limit \\
\hline & Success & Quarterly sales (quarterly net profit) $N E E_{\mathrm{CP}_{7}}$ \\
\hline & Development & Market Share \\
\hline
\end{tabular}


(JPMNT) Journal of Process Management - New Technologies, International Vol. 1, No.3, 2013.

\section{CONCLUSION}

In Table 1. can be presented which may lead to economic parameters that provide the competitive prices of products on the market $N E E_{C P}$ generated in the production environment using the re-engineering (Figure 1).

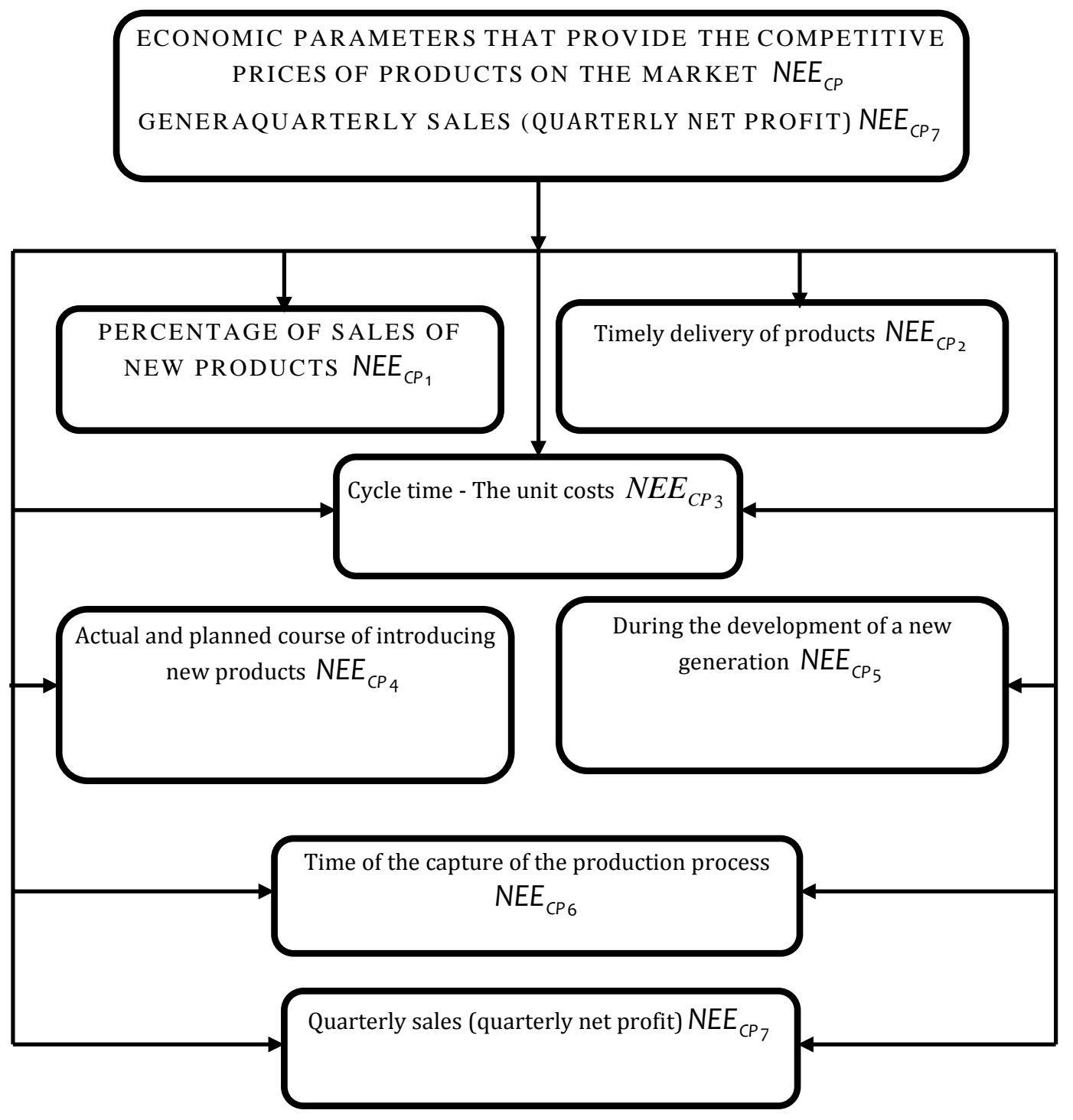

Figure 1. Economic parameters that provide the competitive prices of products on the market resulting in a production environment using the re-engineering 


\section{REFERENCES}

1. R. Cvejic, S. Stefanovic, R. Lojanicic, REENGINEERING MODEL OF BUSINESS PROCESSES IN SMALL AND MEDIUM ENTERPRISES - MONITORING THE ECONOMIC PERFORMANCE OF BUSINESS SYSTEMS, Lucrarea trimisă redacției Metalurgia International a fost acceptată spre publicare în numărul din 2013., ISSN 1582 - 2214, “METALURGIA INTERNATIONAL" is introduced in THOMSON SCIENTIFIC MASTER JOURNAL LIST, letter M, position 440.

2. S. Stefanovic, D. Ilic, R. Cvejic, ANALYSIS OF MONITORING OF CONNECTION BETWEEN RE-ENGINEERING ECONOMIC PARAMETERS IN SMALL AND MEDIUM ENTERPRISES USING THE METHOD OF CREATING OPTIMAL QUESTIONNAIRE, International Journal of Management Research and Development (IJMRD), Volume 3, Number 1, str. 1-7. (2013) Journal Impact Factor (2012): - 1.3560 Calculated by GISI.

3. S. Stefanović, R. Cvejic, D. Kostic, FUNCTIONS THAT CAUSATIVE AFFECTS TO THE IMPLEMENTATION OF REENGINEERING FROM THE ASPECT OF GENERAL FINANCIAL PARAMETERS, Lucrarea trimisă redacţiei Metalurgia International a fost acceptată spre publicare în numărul din 2013., ISSN 1582 - 2214, "METALURGIA INTERNATIONAL" is introduced in THOMSON SCIENTIFIC MASTER JOURNAL LIST, letter M, position 440. vol. 18 SPECIAL ISSUE NO. 8, str. $240-$ 246 (2013).

4. S. Stefanovic, R. Cvejic, LINEAR PROGRAMMING OF BASIC ECONOMIC PARAMETERS USED AT REENGINEERING IN SMALL AND MEDIUM ENTERPRISES, INTERNATIONAL JOURNAL OF MANAGEMENT (IJM), Volume , Number , str. 31 - 43 . Journal Impact Factor (2012): 3.5420 (Calculated by GISI), India.

5. S. Stefanović, R. Cvejic, V. Vucic, FORMATION OF ALGORITHMS REENGINEERING THROUGH THE BLOCK DIAGRAMS IN THE TRANSITIONAL ECONOMY CONDITIONS WITH FOCUS ON MANAGEMENT IN SMALL AND MEDIUM ENTERPRISES, Lucrarea trimisă redacţiei Metalurgia International a fost acceptată spre publicare în numărul 2013., ISSN 1582 - 2214, “METALURGIA INTERNATIONAL" is introduced in THOMSON SCIENTIFIC MASTER JOURNAL LIST, letter M, position 440. vol. 18 SPECIAL ISSUE NO. 8, str. 197 - 204 (2013).

6. S. Stefanović, S. Trajković, Ž. Adamović, R. Milišić, D. Malešević, OSNOVE PREDUZETNIČKOG MENADŽMENTA, Tiraž 200., Strana 335, Izdavač: Društvo za energetsku efikasnost, Banja Luka, 2010., Republika Srpska, ISBN 978 - 99955 - 44 - 11 - 9, Narodna i univerzitetska biblioteka Republike Srpske.

7. Sefanović S., Economic effects of reengineering in small and medium enterprises, Ph.D. Thesis, Megatrend University, Belgrade, 2010.

8. Stefanovic S., Parmetri overall financial functions of a small or medium-sized enterprises that causally affect the implementation of reengineering in transition, Scientific - VOCATIONAL magazine "Reengineering", no. 3 - 4, 2008th, p. 89-93, Zrenjanin, ISSN 1820-7294 UDK 005 ${ }^{\text {th }}$

9. V. Vucic, S. Stefanović, HOLDERS OF ECONOMIC IMPACTS OF REENGINEERING PROCESS IN SMALL AND MEDIUM ENTERPRISES, Lucrarea trimisă redacţiei Metalurgia International a fost acceptată spre publicare în numărul 2013., ISSN 1582 - 2214, "METALURGIA INTERNATIONAL" is introduced in THOMSON SCIENTIFIC MASTER JOURNAL LIST, letter M, position 440. 